University of Wyoming College of Law

Law Archive of Wyoming Scholarship

Winter 1999

Bajakajian: New hope for escaping excessive fines under the civil false claims act

Melissa Ballengee Alexander

Follow this and additional works at: https://scholarship.law.uwyo.edu/faculty_articles

Part of the Civil Law Commons, Health Law and Policy Commons, Medical Jurisprudence Commons, and the Torts Commons 


\title{
Bajakajian: New Hope for Escaping Excessive Fines Under the Civil False Claims Act
}

\author{
Melissa Ballengee
}

$\mathrm{E}$ ver since the U.S. Attorney General named health care fraud as the government's second highest priority after violent crime, the government has cracked down on health care fraud and abuse. ${ }^{1}$ Some of this crackdown has been needed. ${ }^{2}$ The General Accounting Office (GAO) estimates that as much as 10 percent of all government expenditures on health care are being siphoned out of the system because of fraud or abuse. ${ }^{3}$

The extreme measures taken to curb health care abuse have raised eyebrows, however. ${ }^{4}$ The American Medical Association and the American Hospital Association both have been vocal in their disapproval, describing the current enforcement initiative as "absolutely out of control." The associations even went so far as to file suit to enjoin the government's actions. ${ }^{6}$

Legislators also appear to question the government's tactics. ${ }^{7}$ Bills have been introduced in both the U.S. House of Representatives and the Senate to revise the Civil False Claims Act (FCA) to protect health care providers better from being sued for simple billing errors. ${ }^{8}$ Both bills would create a safe harbor for providers that are in substantial compliance with a model compliance plan and would require the government to prove its cases by "clear and convincing evidence." The House's proposed Health Care Claims Guidance Act would also institute a safe harbor for providers that relied on erroneous information provided by a federal agency and limit liability to cases in which the government alleges a material amount of damages. ${ }^{10}$ The Senate's version would cap penalties and offer a safe harbor for claims submitted based on a fiscal intermediary. ${ }^{11}$ The Department of Justice (DOJ) and Office of the Inspector General (OIG) are strongly opposed to both bills.

Journal of Law, Medicine \& Ethics, 27 (1999): 366-79. (C) 1999 by the American Society of Law, Medicine \& Ethics.
Courts also express dissatisfaction with the government's methods. The U.S. Supreme Court characterized the fines imposed on one health care provider as grossly disproportionate. ${ }^{12}$ In another case, an appellate court chastised the government for its relentless pursuit of astronomical, unpayable fines. ${ }^{13}$ In yet another case, a federal district court described the government's tactics as heavy-handed and probably wrong. ${ }^{14} \mathrm{Few}$ health care claims are actually litigated under the FCA because of the high stakes. ${ }^{15}$ In many of the cases that have been litigated, courts have decried the current enforcement scheme. ${ }^{16}$

DOJ and OIG admit that some providers' concerns are legitimate. ${ }^{17}$ To ensure that future health care investigations proceed in a fair manner, both DOJ and OIG have issued new enforcement guidelines to their staffs. ${ }^{18}$ They have also launched new compliance initiatives. ${ }^{19}$ For example, OIG has published multiple, sector-specific model compliance plans and a provider self-disclosure protocol summary. ${ }^{20}$ These new initiatives are aimed at helping providers achieve compliance rather than punishing noncompliance.

Although the investigative environment appears to have improved somewhat in response to these changes, evidence indicates that inappropriate and overzealous enforcement remains a problem. ${ }^{21}$ GAO's August 1999 report on DOJ's use of the FCA indicates that abusive practices, while diminished, continue to linger particularly in the laboratory unbundling initiative. ${ }^{22}$ As a result, some providers continue to seek enforceable legal protection. ${ }^{23}$ The best protection would be to pass the legislation currently proposed by Congress, but this solution may prove impossible, at least for the present. ${ }^{24}$ Hence, I explore another alternative-the protection provided by the U.S. Constitution.

Under the Constitution, the government's current use of the FCA poses two potential problems. First, health care 
providers lack criminal procedural protections when facing civil penalties that can total millions of dollars and administrative sanctions that can include exclusion from all government programs. ${ }^{25}$ Second, some of the civil fines imposed appear grossly disproportionate both to the health care provider's offense and to the damages suffered by the government. ${ }^{26}$

The Supreme Court has attempted to remedy the lack of procedural protections for large civil penalties in the past. ${ }^{27}$ Concerned that Congress, by imposing such large fines to deter quasi-criminal conduct, was doing an endrun around important procedural protections, the Court required that defendants be given criminal procedural protections when defending against civil statutes that were "punitive" or "criminal in nature." ${ }^{28}$ Recently, however, it has all but abandoned this attempt as unworkable. ${ }^{29}$

Although turning away from providing additional procedural protections, the Supreme Court may have started down the path to a better solution. Today, it appears poised to monitor the substantive result of large civil fines under the Eighth Amendment's Excessive Fines Clause. ${ }^{30}$ I trace the Supreme Court's path, evaluate it, and explain how providers may be able to use the Excessive Fines Clause to reduce fines under the FCA. ${ }^{31}$ Although I only address the FCA, the analysis is also applicable to fines imposed against health care providers under the Civil Monetary Penalties Law and the Program Fraud Civil Remedies Act. ${ }^{32}$

Section one illustrates how a lack of adequate procedural protections, an irrational fine computation mechanism, and misplaced incentives sometime combine to produce excessive fines against health care providers. Section two explores how the Supreme Court has wrestled with the idea of applying criminal procedural protections to civil statutes that impose large monetary fines and evaluates this approach. Section three analyzes the Court's latest solution, a substantive review of fines. In particular, I describe the decision in United States $v$. Bajakajian, illustrate how providers can use that decision to argue for a reduction of fines under the FCA, and assess the strengths and weaknesses of substantive review. Finally, in section four, I appraise increased procedural protections and substantive review as a cure for the constitutional infirmity of some large civil fines. I also offer, but ultimately reject, a different judicial solution.

Although readers may disagree that the FCA's per claim fine is not sufficiently tailored to culpability or damages, my goal is to urge that some of the energy spent fighting fraud and abuse be redirected to helping providers achieve compliance. In fact, the government has already begun moving in this direction on its own.

\section{Potential problems with the FCA's application to} health care providers

\section{Background}

The government seems to favor the FCA in its battle against health care fraud for two reasons. First, monetary penalties under the FCA frequently reach into tens of millions of dollars. ${ }^{33}$ Second, liability is relatively easy to obtain. Under the FCA, health care providers who knowingly make false or fraudulent claims to the government are fined $\$ 5,000$ to $\$ 10,000$ per claim in addition to treble damages. ${ }^{34}$ This can result in huge fines because some health care providers routinely submit thousands of claims to the government each year. ${ }^{35}$

What is more, under the FCA, providers enjoy few procedural protections. In a typical scenario, health care providers being investigated for fraud confront parallel criminal, civil, and administrative proceedings. ${ }^{36}$ They face imprisonment and fines under criminal law, more large fines under civil law, and exclusion from further participation in government health care programs under administrative law. Throughout the civil and administrative proceedings, providers lack criminal procedural protections. They are forced to turn over documents and to testify to incriminating evidence. ${ }^{37}$ Moreover, they are not protected from further civil or administrative proceedings if criminally convicted, and the government only has to prove its civil case against them by a preponderance of the evidence.

The FCA's relatively low scienter requirement exacerbates this lack of procedural protections. A provider can be found liable even though it had no actual knowledge that the claim submitted was false. ${ }^{38}$ The statute only requires deliberate ignorance or reckless disregard for the truth or falsity of the claim. ${ }^{39}$ Further, providers have an affirmative obligation to ensure that their billing is correctly submitted. ${ }^{40}$ They face liability even if they did not prepare the bills themselves or acted at the direction of a consultant. ${ }^{41}$ This burden can be staggering given the voluminous, often ambiguous health care regulations. ${ }^{42}$

Although most cases that the government has pursued involve intentional conduct or gross lack of supervision (that is, legitimate, fraudulent activity), not all do. The recent trend toward national enforcement initiatives is particularly troubling, because these initiatives focus on commonly misunderstood regulations that have been misinterpreted throughout the health care industry for years without government complaint. ${ }^{43}$ More troubling still, DOJ officials sometimes target the largest institutions with the most claims and the deepest pockets, even though these highly respected institutions had no intent to defraud the government. ${ }^{44}$ The current case law does not reflect this problem because these institutions invariably settle even nonmeritorious claims to avoid potential liability of millions of dollars. ${ }^{45}$

Although the new DOJ-OIG guidelines seek to combat these problems, the FCA creates a strong financial incentive for enforcement. ${ }^{46}$ Nationally, DOJ and OIG receive praise based on the amount of money returned to the 
federal government. Congress's recent concern with overaggressive enforcement should mitigate any misplaced incentives at the national level, but financial incentives remain a problem at the local level. To make a name for themselves, local officials sometimes pursue claims that do not fall within the DOJ-OIG enforcement guidelines. ${ }^{47}$ Qui tam plaintiffs add to this problem. Even if the government only pursues cases that fall within the guidelines, the text of the FCA allows liability in a much greater range of cases. Qui tam plaintiffs can seek recovery in any case that meets the minimal requirements of the FCA. ${ }^{48}$ The government has an incentive to join in these cases, but, even if it chooses not to, providers face enormous potential liability. By 1997, judgments in qui tam cases topped $\$ 625$ million. ${ }^{49}$ Given the new advertising campaign by the Health Care Financing Administration (HCFA) to encourage more people to come forward and to report fraud and abuse, this number will likely continue to increase.

A combination of the threat of inordinate liability under the FCA and the possibility that the government will impose the "death penalty"-exclusion from all state and federal programs-causes most providers to seek settlement even if they view it as little more than extortion..$^{50}$ The cases that have been litigated show that this bombardment of large penalties, without criminal procedural protections, causes many courts to question the current system for combating health care fraud. Although courts have expressed a variety of concerns, I focus specifically on how per claim penalties can result in disproportionate fines. This potential constitutional infirmity still derives in part, however, from the totality of the circumstances. Large fines, even if disproportionate, would be less troubling if providers enjoyed criminal procedural protections or if the FCA required that providers act with specific intent to defraud the government.

\section{Arbitrary fine computation}

Application of the FCA to health care providers can often result in disproportionate fines that bear little relation to culpability or actual damages. Two factors come together to produce this result. First, the FCA uses a per claim fine as well as treble damages to compute liability. ${ }^{51}$ By itself, this characteristic is not necessarily offensive. The per claim fine was included to ensure that the full cost of false claims was captured and to penalize the act of making a false claim. This penalty may not be particularly well tailored, but it provides rough remedial justice in most cases. ${ }^{52}$ Unfortunately, health care providers present a relatively unique case. They routinely submit thousands of claims to the government annually. When numerous small claims are at issue, the FCA's per claim fines can metamorphize from rough remedial justice to grossly disproportionate penalties. The examples below illustrate how this can occur.

\section{Not proportional to damages}

Fines under the FCA do not seem to correlate to damages in any straightforward way. A provider that submits numerous claims may cause the government significantly less harm than a provider that files a single false claim. Nevertheless, the provider that submits more claims in all likelihood will face a significantly higher fine as a result of the per claim charge. For example, by filing 500 false claims, a provider may cost the government $\$ 1,000$. That provider, however, would be liable for $\$ 3,000$ in treble damages, but $\$ 2.5$ to $\$ 5$ million in per claim charges. Meanwhile, another provider that makes one false claim for $\$ 100,000$ is liable for $\$ 300,000$ in treble damages, but only $\$ 5,000$ to $\$ 10,000$ in per offense charges. Thus, the provider that costs the government $\$ 1,000$ in false claims ends up paying over $\$ 2.5$ million in fines, while the provider that costs the government $\$ 100,000$ in false claims pays only slightly over $\$ 300,000$ in fines. In other words, a single claim offender could cost the government 100 times more money yet pay ten times less. ${ }^{53}$ These results indicate that penalties under the FCA are often not proportional to damages.

Not only are per offense charges not proportional to damages, but also there is no evidence that the number of false claims increases government expenses. If it were possible to prove that each fraudulent claim imposed additional costs, these damages could be addressed directly through the imposition of treble damages. The only remedial justification for adding a per claim fine (instead of relying on treble damages) would be if each fraudulent claim cost the government money in some way that was difficult to detect or prove.$^{54}$ In fact, the opposite seems true. The most difficult-to-prove costs associated with health care fraud are caused by monitoring and enforcement. Prolifičsmall gauge offenders may be easier to catch through monitoring, because they make more false claims. ${ }^{\text {ss }}$ Similarly, the government may have an easier time proving liability when there is more than one offense; this is because multiple offenses make the "knowledge" element of the FCA easier to establish.

\section{Not proportional to culpability}

The per offense charge also appears to bear little rational relation to culpability. ${ }^{56}$ The health care provider that defrauds the government of a small amount of money on many occasions is not per se more culpable than a provider that defrauds the government of a large sum of money once. The argument that providers that file numerous false claims are more culpable than those that file only one fails. A prolific small gauge offender might be less guilty in many different ways. First, the prolific small gauge offender might have acted recklessly whereas the single claim offender acted with specific intent to defraud. Second, the prolific offender may be liable because it failed to monitor adequately its employees or a third-party billing contractor, while the single 
claim offender acted personally. Third, the prolific offender might have detrimentally relied on a consultant's or government official's billing advice, while the single claim offender interpreted the regulation itself. Finally, the prolific small gauge offender might have cost the government significantly less money than the single claim offender.

The FCA attempts to account for greater culpability by allowing judges to impose fines of $\$ 10,000$ per offense rather than $\$ 5,000$ when appropriate. But this judicial discretion is a poor remedy for the problem for prolific offenders. Reconsider the scenario described above. The prolific small gauge offender that filed 500 claims paid over $\$ 2.5$ million even if it was only assessed the $\$ 5,000$ per offense fine. This provider might be liable only because of recklessness for acts by its employees or its billing contractor. The single claim offender that costs the government 100 times as much money pays a fine of only $\$ 310,000$ even if it acted personally, with the specific intent to defraud the government, and the highest per offense charge is applied. As this example illustrates, the prolific small gauge offender's fine bears little rational relation to culpability.

Even if a prolific small gauge offender and a single claim offender both act personally, with specific intent, and cost the government the same amount of money, the small gauge offender would still face disproportionate liability. Returning to my example, assume now that the prolific small gauge offender and the single claim offender both cost the government $\$ 100,000$; both acted personally and with specific intent. Some would argue that, all things being equal, the provider that filed multiple false claims acted with greater culpability because its conduct demonstrates a pattern of behavior or because it repeatedly chose to defraud the government. This argument makes a deontological assumption; but even if the basic premise is correct, the results under the FCA are still troubling. The prolific small gauge offender still faces liability of over $\$ 2.8$ million whereas the single claim offender faces a fine of $\$ 310,000$. Whatever increased culpability might be attributed to having filed several claims, it does not equate to a difference in fines of $\$ 2.5$ million (assuming the lowest per offense charge). ${ }^{57}$

\section{The FCA miscounts}

The FCA's per claim charge has another problem matching liability to culpability: it miscounts. Under the FCA, each application of a single misinterpretation triggers the per claim penalty. If a health care provider misunderstands a Medicare regulation, it will follow that interpretation in all cases. Although this course leads to numerous false claims, the provider only has made one mistake recklessly, misinterpreting one regulation. ${ }^{58}$

Prolific small gauge offenders are particularly vulnerable to the FCA's weaknesses. Many times, the largest part of the penalty is the mandatory per offense charge. Although judges might believe that the fines are excessive, most courts have held that the minimum per offense charge is mandatory under the text of the FCA. ${ }^{59}$ Hence, the more small false claims a provider submits, the greater the disparity between the harm caused and the penalty imposed.

\section{Past attempts at procedural solutions}

\section{The Kennedy-Ward test: criminal v. civil}

Initially, the Supreme Court sought to control excessive fines by providing criminal procedural protections. This required determining when sanctions imposed by civil statutes rose to the level at which additional procedural protections were required. The Court approached this classification problem by categorizing otherwise civil statutes as "criminal in nature" when they warranted added procedural protections. ${ }^{60}$ In Kennedy v. Mendoza-Martinez, the Supreme Court found two sections of the 1952 Immigration and Nationality Act unconstitutional because the Act was criminal in nature but failed to provide the procedural safeguards constitutionally required for criminal prosecution. ${ }^{61}$ The Court presented a multifactor test to determine when a statute was criminal in nature, stating that "absent conclusive evidence of the congressional intent ... these factors must be considered in relation to the statute on its face." ${ }^{62}$ The test listed seven factors:

[(1)] "whether the sanction involved an affirmative disability or restraint,

(2) whether it had historically been regarded as a punishment,

(3) whether it comes into play only on a finding of scienter,

(4) whether its operation will promote the traditional aims of punishment-retribution and deterrence,

(5) whether the behavior to which it applies is already a crime,

(6) whether an alternative purpose to which it may rationally be connected is assignable to it, and

(7) whether it appears excessive in relation to the alternative purpose assigned. ${ }^{63}$

Almost twenty years later, the Court revised the test in United States $v$. Ward ${ }^{64}$ Concerned that the standard in Kennedy was too ambiguous and difficult to administer without providing criminal procedural protections to a vast array of civil cases, the Court narrowed the test. In Ward, it upheld a monetary penalty imposed under the Federal Water Pollution Control Act, stating that the Act was civil in nature and therefore did not violate the defendant's right against self-incrimination. ${ }^{65}$ In reaching its decision, the Court focused on the fact that Congress had intentionally separated civil and criminal penalties in the same statute. ${ }^{66}$ 
The Court stated that the congressional classification of a penalty as civil would not be set aside without the "clearest proof" that the penalty in question was "punitive in either purpose or effect." 67 This dicta raised the level of proof required by the Kennedy test.

The Kennedy-Ward test fails to resolve the excessive fine problem that plagues health care providers that submit numerous claims to the government, because the FCA almost certainly would not be considered criminal in nature. ${ }^{68}$ After all, the legislature intentionally separated the Civil False Claims Act (FCA) from the Criminal False Claims Act. ${ }^{69}$ Under Ward, this separation demonstrates legislative intent that the FCA be treated as a civil statute. ${ }^{70}$ Once the court establishes that the legislature intended a statute to be civil, courts apply criminal procedural protections only when a statute contains the "clearest proof" that the penalty in question is punitive on its face. ${ }^{71}$ This high standard makes surmounting legislative intent impossible in practice and effectively guts whatever protection the Kennedy test once provided.

\section{Halper: punitive $v$. remedial}

Realizing that the Kennedy-Ward test failed to capture statutes like the FCA, which can be criminal as applied, if not on their face, the Supreme Court tried a new approach in United States $v$. Halper. ${ }^{72}$ In Halper, the Court began by asking whether the penalty imposed served a punitive or remedial purpose. ${ }^{73}$ This inquiry bypassed the threshold question presented by the Kennedy-Ward test-whether a statute was criminal or civil in nature. It also switched the inquiry from the nature of the statute on its face to the purpose of the statute as applied, thereby requiring a caseby-case analysis.

In Halper, the Supreme Court held that the government could not bring a claim under the FCA against Irwin Halper who filed sixty-five inflated Medicare claims after the government had already criminally prosecuted him. ${ }^{74}$ The Court reasoned that the FCA serves a punitive purpose, and because Halper had already faced one punishment in court, it would violate the Double Jeopardy Clause to subject him to a second punishment for the same acts. ${ }^{75}$ In deciding that the statute served a punitive purpose, the Court considered the fact that Halper faced potential civil liability of over $\$ 130,000$ for inflated charges that cost the government less than $\$ 600 .^{76}$ The Court found the disparity between the government's expenses and the defendant's potential liability so great that it held that the sanction bore no rational relation to compensating the government but rather served as an additional punishment. ${ }^{77}$

Halper's punitive versus remedial test afforded prolific offenders with some protection from excessive fines. By being granted criminal procedural rights, prolific small gauge offenders gained protection from double jeopardy and self- incrimination. These protections consolidated sanctions, but, for several reasons, Halper still failed to provide sufficient protection from excessive fines.

First, Halper failed to produce a reliable precedent. ${ }^{78}$ Courts proved unable to differentiate statutes that required additional procedural protection from those that did not, based on the punitive versus remedial distinction. ${ }^{79}$ Thus, Halper produced a judicial quagmire rather than a clear precedent. ${ }^{80}$ Without real guidelines on how to apply the distinction in a sensible manner, many courts continued to rely on the Kennedy-Ward test.

Second, the criminal procedural protections provided by Halper cannot prevent excessive fines. Even with procedural protections, judges remained compelled by the mandatory nature of the FCA's per offense charge to impose arguably disproportionate penalties on prolific offenders. ${ }^{81}$ Criminal procedural protections cannot change this. The Double Jeopardy Clause at issue in Halper does not monitor the amount of a fine; it only monitors a fine imposed after criminal punishment. The Double Jeopardy Clause does not protect prolific offenders from excessive liability or even multiple sanctions. It only ensures that the government imposes all sanctions at the same time. If procedural protections cannot change the ultimate result, they offer little solace to providers that suffer excessive liability under the FCA.

\section{The impact of procedural protections: an analogy to criminal law}

Nevertheless, the question remains whether lack of proportionality between an offense and its punishment necessarily creates a constitutional infirmity. After all, the judicial system refuses to perform ex post proportionality review of criminal punishments unless they violate the prohibition against cruel and unusual punishment in the Eighth Amendment. ${ }^{82}$ Courts have read this prohibition so narrowly that, in practice, criminal sentences are never reviewed ${ }^{83}$ Perhaps, therefore, there is no reason to review civil fines.

After all, criminal sentences have several characteristics in common with fines under the FCA. The legislature sets both punishments prospectively, offering some protection against unfair results because the penalties are set without any knowledge of to whom they will apply. This prospective setting also enables legislators plenty of time to research and debate the proper level for the sanction and to revise it if they change their minds. Despite these protections, the punishments that result from the criminal justice system, like the punishments from fines applied to prolific offenders, are often not "fair" because district attorneys can charge-stack. Like the counting problem under the FCA, prosecutors often manipulate the definition of crimes so that conduct violates several statures. Therefore, criminal 
punishments frequently do not correspond to the gravity of the offense, yet courts have not been willing to review disproportionate criminal sentences. ${ }^{84}$

Criminal punishment is different, however. First, defendants enjoy procedural protections on the front end, like the right against self-incrimination and double jeopardy, and a heightened burden of proof. Second, criminal sentences are more narrowly tailored than penalties under the FCA. ${ }^{85}$ These protections already curb prosecutorial abuse. Individuals charged with fines receive no such protections.

Providing criminal protections, even if an inadequate solution to excessive fines, may be sufficient to satisfy any constitutional obligation. Ultimately, the solution in Halper failed because the Court found the distinction between punitive and remedial statutes impossible to administer. As the Court eventually admitted, almost all civil statutes serve at least some punitive purpose. ${ }^{86}$ As such, a punitive purpose test is so grossly overinclusive that it becomes virtually meaningless. ${ }^{87} \mathrm{~A}$ punitive purpose test requires criminal procedural protections for almost all civil statutes, a result far too costly to implement. Criminal protections cost taxpayers an enormous amount of money, require greater judicial resources, and often impede punishment on technical grounds. Although these additional expenses might be merited when personal liberty is at stake, few people would like to see the same resources devoted to every individual who faces a fine. Unable to arrive at a sensible test to distinguish which punitive statutes merited protection, the court abandoned the attempt to evaluate statutes as applied.

\section{Hudson: a return to the Kennedy-Ward test}

Displeased with the doctrinal difficulties that resulted from Halper, the Supreme Court emphasized that Halper presented a rare case and that the holding was extremely narrow. ${ }^{88}$ In December 1997, the Court in large part disavowed the analytical method of Halper and returned to the civil versus criminal distinction of the Kennedy-Ward test. ${ }^{89}$ In Hudson v. United States, the court looked at the legislative intent on the face of the statute to determine if Congress had intended the statute to be civil. ${ }^{90}$ When it found that Congress had so intended, the Court held that only the "clearest proof" that the sanctions were substantively criminal would cause the Court to demand procedural protections. ${ }^{91}$ Although the statute at issue penalized behavior that was also criminal and served a deterrent purpose, the Court held that these facts did not render the statute criminal, and so, the Double Jeopardy Clause had not been violated..$^{92}$

While opting to revert to the Kennedy-Ward test, the Court pointed out that other constitutional provisions address many of the ills at which the Halper decision was directed, ${ }^{93}$ specifically, the Due Process, Equal Protection, and Excessive Fines Clauses. ${ }^{94}$ Each of these provisions addresses substantive results. By refocusing its attention on substantive provisions of the Constitution, the Court implied that ex post substantive review is necessary to cure disproportionate fines. In Hudson, the Court appears to abandon the attempt to control excessive fines through ex ante procedural protections. ${ }^{95}$

Within months of this statement, the Court issued Bajakajian, finding a statute unconstitutional as applied under the Excessive Fines Clause. ${ }^{96}$ Bajakajian represents the Court's first attempt to resolve disproportionate fines by monitoring substantive results rather than by providing procedural protections.

\section{Bajakajian: ex post substantive review}

\section{Bajakajian}

In Bajakajian, the Supreme Court held that requiring a defendant to forfeit $\$ 357,144$ because he knowingly attempted to leave the country without reporting the currency, pursuant to 18 U.S.C. $\$ 982(a)(1)$, violates the Eighth Amendment's Excessive Fines Clause. ${ }^{97}$ The Court reasoned that a fine violates the Eighth Amendment if it is "grossly disproportional" to the defendant's offense. ${ }^{98}$ This holding creates a two-prong test. First, a court must determine whether a monetary penalty qualifies as a "fine" within the meaning of the Excessive Fines Clause. ${ }^{99}$ The Court defines "fine" as a payment to the government as "punishment" for an offense. ${ }^{100}$ Under the facts of Bajakajian, the Court found that criminal in rem forfeiture is a "fine" within the meaning of the Eighth Amendment because it includes a scienter requirement, serves no remedial purpose, and has historically been considered punitive. ${ }^{101}$ Second, a court must determine whether a fine is "grossly disproportional" to the defendant's wrong. ${ }^{102}$ The Court has not articulated a clear test for this determination; instead, it instructs lower courts to weigh the amount of the fine against the gravity of the defendant's offense, giving deference to Congress because punishments are inherently imprecise. ${ }^{103}$

In Bajakajian, the Court cited several reasons for finding the forfeiture grossly disproportional: (1) the defendant's crime was only a reporting offense; $;^{104}(2)$ it was unrelated to other criminal activity; ${ }^{105}$ (3) the defendant did not fit into the class of people for whom the statute was principally designed; ${ }^{106}$ (4) the harm the defendant caused the government was negligible, as was the maximum criminal sentence for the offense; ${ }^{107}$ and (5) there was no articulable correlation between the amount of the fine and any government injury. ${ }^{108}$ These factors are not exhaustive; the Excessive Fines Clause requires a case-by-case analysis.

\section{Application to providers that submit numerous claims}

Courts likely will extend Eighth Amendment protection to health care providers facing enormous potential liability 
under the FCA. ${ }^{109}$ In Halper, the Supreme Court evaluated a prolific small gauge offender who had been sued under the FCA and found that the monetary penalties imposed were punitive, not remedial. ${ }^{110}$ The unanimous Court also concluded that the sanctions were "overwhelmingly disproportional" to the government's losses and expenses, and bore no rational relation to the goal of compensating the government. ${ }^{111}$ If courts find the logic in Halper persuasive, both prongs of the Bajakajian excessive fines test will be satisfied. Courts will consider the FCA fines punitive as applied to prolific small gauge offenders, and the fines imposed will be struck down as grossly disproportional. The primary effect of this extension will be to make the per offense charge permissive rather than mandatory. With Bajakajian, judges now have the discretion to reduce fines that overpunish prolific offenders.

This result is not automatic, however, because the Court dismissed Halper's analysis as unworkable only six months ago. ${ }^{112}$ More likely, this dismissal can be explained by a decision that the punitive versus remedial distinction is improper for double jeopardy analysis but acceptable for excessive fines analysis. ${ }^{113}$ Certainly, prior to Halper, the Double Jeopardy Clause had only been applied to criminal sanctions, whereas the Supreme Court had never applied the Excessive Fines Clause. As such, the Excessive Fines Clause offered a relatively clean slate for interpretation and provided a more logical constitutional hook to protect against overwhelmingly disproportional government fines. This explanation is supported by the close proximity in time between the Court's statement that the concerns addressed in Halper could be addressed through other constitutional provisions and Bajakajian, which applies the Excessive Fines Clause for the first time, adopting analysis almost identical to that used in Halper. ${ }^{114}$

This theory is also supported by the manner in which the Court disavowed Halper. Rather than stating that Halper reached the wrong conclusions, the Court stated that Halper began with the wrong inquiry. ${ }^{115}$ The Court did not take issue with the conclusions in Halper-that the FCA penalties imposed on prolific small gauge offenders were punitive and disproportional. ${ }^{116}$ Instead, it argued that, under proper double jeopardy analysis, Halper should have asked whether the FCA was criminal or civil on its face, rather than whether the FCA was punitive or remedial as applied. ${ }^{117}$

Even if courts do not look to Halper, they will likely find that FCA penalties imposed on prolific small gauge offenders in the health care industry violate the Excessive Fines Clause. After all, the factors that the Court relied on in Bajakajian support the classification of FCA penalties as fines. First, the FCA has a scienter requirement, and the conduct it penalizes is also a crime. Second, the FCA serves a punitive purpose. In the case of many health care providers, the monetary penalty far exceeds the cost to the government of the false claim, even including the money spent investigating and prosecuting the claim. Under Bajakajian, a penalty that exceeds its remedial purpose serves a punitive purpose. Third, the FCA penalty is, at least in part, historically punitive. In Bajakajian, the Court stated that double indemnification had historically been viewed as a complete remedy. If double indemnification fully compensates the government, treble damages accompanied by a $\$ 5,000$ to $\$ 10,000$ per offense penalty must be historically punitive, particularly when applied to prolific small gauge offenders.

If the court determines that the FCA's application to prolific offenders is punitive, then it must decide if the fines imposed are grossly disproportional to the health care provider's offense. This requires a fact-specific inquiry, and the holding in Bajakajian only tells lower courts that they should compare the amount of the fine with the gravity of the offense. This standard allows considerable judicial discretion, making predicting the behavior of lower courts more difficult.

Courts likely will find the fines imposed under the FCA on prolific offenders grossly disproportional in many cases. Courts are most apt to find the penalties unconstitutional when false claims result from commonly misunderstood Medicare regulations, when the government has acquiesced to the provider's interpretation for years, when providers relied on expert consultants or advice from administrators at HCFA, or when providers did not intend to defraud the government. Courts may also sympathize with providers whose motives are suspect if they cost the government a relatively small amount of money in relation to the enormous liability due to the large number of claims. Some courts may never consider fines under the FCA grossly disproportional, because they view Medicare and Medicaid fraud as such a serious offense. These courts will argue that defrauding the government is significantly worse than the reporting offense in Bajakajian, reasoning that the government needs strong deterrent measures to control rampant health care fraud.

Bajakajian leaves courts with enormous discretion to weigh the seriousness of the offense against the size of the fine. This discretion releases courts from the mandatory per offense fine. Although ex post proportionality review will not make the FCA directly tailored to culpability or damages, it will allow recourse from the more egregious cases of liability. If the current FCA cases are any indication, judges will welcome this freedom and use it to reduce some fines imposed against providers. This protection should empower more providers to challenge their cases in court.

\section{The impact of ex post proportionality review: $a$ lesson from punitive damages}

Bajakajian offers a new shield for health care providers. It 
does not provide the criminal procedural protections that the FCA arguably requires, but it may provide a better safeguard against potential legislative and prosecutorial abuse of power by reviewing substantive results. The benefits of ex post proportionality review are obvious. This type of case-by-case review allows courts to address the problem of excessive liability directly. Unlike procedural protection, which leaves judges powerless to alter the final results when proper procedures produce irrational conclusions, proportionality review enables judges to ensure that the end result is fair. Further, proportionality review is a more precise tool. It enables judges to reduce a penalty to a reasonable amount without having to bar it completely. Procedural protections do not enable judges to adjust fines in this way.

Unfortunately, the disadvantages of ex post proportionality review are equally apparent. Substantive review tests are very difficult for courts to administer. Bajakajian asks judges to determine whether a fine is grossly disproportionate to the gravity of the defendant's offense, but the concept of proportionality is very difficult to unpack. ${ }^{118}$ The Supreme Court directs judges to consider the proportionality of each fine in relation to the gravity of the offense, but there is little justification for the judiciary second-guessing a difficult legislative value judgment as to the seriousness of an offense. Substantive reviews require courts to exercise subjective judgments. Courts have difficulty performing such reviews in a fair and consistent manner, and they seldom bring any special expertise to the process. Consequently, some legal scholars argue that there must be an independent justification for why courts would resolve the issue better than the legislature. ${ }^{119}$ Otherwise, scholars argue, courts should not embark on substantive reviews.

The Supreme Court's struggle to articulate relatively objective criteria for proportionality in BMW of North America, Inc. v. Gore illustrates the problem. ${ }^{120}$ In $B M W$, the Court overturned a punitive damages award for $\$ 2$ million as excessive when actual damages were estimated at $\$ 4,000 .{ }^{121}$ The Court argued that the Fourteenth Amendment's Substantive Due Process Clause prevented excessive punitive damages. ${ }^{122}$ The Court relied on three factors to determine proportionality: (1) the degree of reprehensibility of the plaintiff's conduct; (2) the ratio of actual or potential harm to the award; and (3) the difference between the punitive damages awarded and punishment under civil or criminal statutes for similar misconduct. ${ }^{123}$ The Court also stated that no one factor could be dispositive and that other factors might sometimes come into play. Lower courts have had a difficult time applying these ambiguous criteria in a consistent manner. ${ }^{124}$

The ex post proportionality review used for punitive damages closely parallels the Court's recently announced ex post proportionality review of fines. This similarity is not surprising because punitive damages and fines serve similar purposes. Both exceed proven remedial costs in part because other damages seem likely to have occurred that are too difficult to measure or prove and because suits are not always prosecuted. ${ }^{125}$ Thus, both large fines and punitive damages are required to deter bad behavior fully. Fines and punitive damages also have an expressive and retributive purpose. ${ }^{126}$ They reflect the community's consensus that certain behavior merits punishment. The more egregious the conduct, the larger the punishment should be.

Initially, however, the justification for monitoring punitive damages awards appears much stronger than the argument for reviewing fines. First, fines do not pose a notice problem. They are significantly more predictable; a defined conduct triggers a predetermined penalty. This makes planning possible. In contrast, punitive damages cannot be predicted. Jury behavior is notoriously erratic. ${ }^{127}$ Two juries hearing the same facts, finding the same level of culpability, often award vastly different punitive damages. ${ }^{128}$ This lack of predictability makes it difficult for punitive damages to deter sufficiently malign behavior without overdeterrence. ${ }^{129}$

Second, fines do not suffer from the procedural weaknesses often attributed to punitive damages. Juries are often criticized for being influenced by prejudice and stereotypes. Fines are less arbitrary; a defined conduct triggers a predetermined sanction. Therefore, similarly situated defendants are treated similarly. This uniform application decreases discrimination problems. It also prevents the unfairness that results from different juries awarding different punitive damages for similar conduct. Further, it decreases the likelihood that the relative skill, experience, and knowledge of the trial attorney will be a significant factor. ${ }^{130}$

Fines are also more rational. Legislatures have the opportunity to consider fines rationally and fully because they are set in advance. They can hear from interests groups, poll constituents, or research the issues. Even after legislatures set a fine, they can always reconsider it later. In contrast, juries must make a decision on the spot that they cannot reevaluate. This pressure situation, where outside information, opinions, and research are forbidden, creates more arbitrary, less reasoned results.

Moreover, the democratic process already monitors fines. They do not need judicial monitoring because they have a natural democratic check. The legislature sets fines, and if citizens oppose these fines, they can lobby to change them or elect new representatives who will. Juries have no such check. They cannot be voted out because the majority of the population thinks the wrong verdict was reached or that damages were too high.

Finally, a judicial review of fines disturbs the balance of power between the different branches of government. If judges have the power to overturn on vague and arbitrary grounds the legislative will on the proper punishment for certain offenses, this may erode the legislature's power and greatly strengthen the judiciary's. Such a shift in the balance of power could undermine the voice of the people 
because many judges are appointed (often for life), rather than elected. ${ }^{131}$ Reviewing punitive damages awards does not cause this same problem. Jury awards are already part of the judicial system, hence, the judicial branch is merely monitoring its own proper functioning.

These arguments certainly present compelling reasons for the claim that punitive damages pose dangers that fines do not; but, ultimately, the unique danger that fines pose is significant enough to merit judicial supervision. Fines, unlike punitive damages, are set by the legislature, which benefits from their collection. Conversely, juries are disinterested parties. Initially, this factor may not seem overwhelming. Legislators' behavior can be checked through the electoral process, and fines cannot be politically motivated because they apply equally to all. The Bill of Rights, however, explicitly protects citizens from any abuse of government power in certain defined areas, among them is fines. ${ }^{132}$ The Eighth Amendment expressly prohibits the government from imposing excessive fines. ${ }^{133}$ A clear, unstrained reading of it mandates that courts perform an ex post substantive review. ${ }^{134}$ After all, an excessiveness inquiry intrinsically requires evaluating each fine under the particular circumstances. ${ }^{135}$ Fines cannot be "excessive" on their face, but only in relation to the conduct they punish. ${ }^{136}$

\section{Is ex post proportionality review a better solution?}

\section{Procedural protections $v$. ex post proportionality review}

Criminal procedural protections and ex post proportionality review offer some protection to prolific small gauge offenders under the FCA, but both solutions are plagued with administrative difficulties. Criminal procedural protections have three main advantages. First, courts know what criminal procedural protections require. The parameters of the right against self-incrimination and double jeopardy are clearly defined. In contrast, even after courts determine that a fine is excessive, they have no clear guidance as to how much they should reduce the fine. ${ }^{137}$ Thus, ex post proportionality review is likely to be inconsistent. Second, procedural protections can avoid unjust results without a caseby-case analysis. Proportionality review requires that the facts of each case be considered, which necessarily demands enormous judicial resources. Third, providing criminal procedural protections has the ancillary benefit of resolving the insufficient procedural protections problem. Although the end result, reducing excessive fines, is paramount, the procedure is of importance, too. Ex post proportionality review provides a more direct solution to the problem of excessive fines, but it does not have the same spill-over effect-addressing double jeopardy and self-incrimination problems which would be solved by criminal procedural protections.
Despite these disadvantages, ex post proportionality review seems to provides a better solution to excessive fines. First, substantive review addresses the problem directly. Criminal procedural protections often will not prevent excessive fines because procedural protections do not change the mandatory nature of per offense penalties. Thus, multiple claim filers will face disproportionate fines under the FCA even with procedural protections. In contrast, ex post proportionality review changes the per offense penalty from a mandatory to a presumptive fine. This allows judges latitude to reduce unfair fines.

Second, ex post proportionality review is a more precise tool. With substantive review, judges can reduce a fine to prevent it from being grossly disproportional. This flexibility will not guarantee that all fines correspond directly to culpability or damages, but it will facilitate closer matches. Criminal procedural protections only permit judges to strike a fine on procedural grounds.

Third, ex post proportionality review should be easier to administer. Because only grossly disproportionate fines will be reduced, some of the administrative difficulties of Hudson can be avoided. It will not matter that most fines contain at least some punitive element. Although this may mean that most fines satisfy the first prong of the Bajakajian test, only those fines bearing no rational relationship to the gravity of the defendant's offense will be decreased. ${ }^{138}$ Thus, ex post proportionality review does not open the floodgate to review of all civil fines the way criminal procedural protections would. Further, because a substantive review allows the court only to reduce a fine, the court has more room to apply a difficult standard. Criminal procedural protections either apply or not.

\section{Another procedural alternative}

Becausé criminal procedural protections are too difficult to administer and offer at best a limited solution, and knowing that ex post proportionality review may also prove impossible to administer effectively, another ex ante procedural alternative should be considered. Courts could prohibit all fines that charge a penalty per each claim without setting a ceiling on per claim penalties. ${ }^{139}$ This alternative has many advantages. First, it would solve the proportionality problem under the FCA without being as difficult to administer. A blanket rule, it provides clear guidance to lower courts as to which penalties are constitutionally prohibited. Barring unrestrained per claim penalties would also allow courts to examine statutes ex ante on their face. This ex ante review would greatly decrease inconsistencies between courts and would cost less to administer.

Further, although judges are poorly equipped to second guess legislative intent regarding the severity of sanctions required to deter malign behavior, judges are better qualified to determine when a fine structure will produce 
irrational results. A per offense fine structure obscures the fine's application. This characteristic makes it difficult for legislatures to foresee the unjust results the fine may produce. Thus, the judiciary is more justified in questioning the legislative judgment in these cases.

Unfortunately, prohibiting unrestrained per offense charges also has some significant drawbacks. Striking all fines that charge a penalty per offense without setting a ceiling is both over- and underinclusive. The solution is overinclusive because it will overturn numerous fines that may never be applied in unconstitutional ways. As the Court stressed in Halper and Bajakajian, grossly disproportionate results only occur in rare cases. ${ }^{140}$ The solution is underinclusive because it does not capture cases in which the ceiling would be a disproportionate fine or the fine is excessive but did not result from a per offense charge.

This solution also appears somewhat arbitrary because it does not link directly to any text in the Constitution. Arguably, it could be required on Substantive Due Process grounds, but it certainly does not have the textual justification that a substantive review of excessive fines enjoys. Given the extent to which this prohibition would encroach on legislative statute writing, a stronger textual justification in the Constitution may be required.

Finally, although eliminating unrestrained per offense charges may be easier to administer because it operates ex ante, it presents unique administrative difficulties. First, the proper ceiling itself is a subjective judgment. If courts set the appropriate ceiling, this encroaches on the legislature's right to determine civil penalties. Besides, judges have no particular expertise in determining appropriate ceilings and are not as responsive to the electorate. Setting a ceiling is far too subjective and fact-intensive an inquiry for courts to excel at it. On the other hand, if the legislature sets the ceilings, it may set them so high that the resulting fines are still excessive in many cases. Thus, the demands of the Eighth Amendment would not be met. Worse still, a fair ceiling, without more nuanced liability guidelines, may not exist. It is difficult to imagine a ceiling that would capture the full costs to the government in all cases without setting the ceiling so high that it allows people to be grossly overpenalized in some circumstances.

Second, effectively eliminating per offense charges requires defining what constitutes a single offense, unless all blanket charges are disallowed. The difficulties defining a given offense are well illustrated by the definition problems in criminal law. It is often difficult for a judge to distinguish offenses from one another, and there is no obvious way to decide when it is slicing too thin. All blanket charges cannot be struck, however, because damages alone do not punish behavior. Sometimes actual damages will be small, but culpability will be great. Statutes must be able to deter misbehavior even when it does not result in provable economic damages. Besides, so many statutes currently contain blan- ket damages that prohibiting such damages would require rewriting half of the civil code.

Given the over- and underinclusive nature of this solution, its failure to conform closely to the text of the Eighth Amendment, and the administrative difficulties, the Court seems best advised to pursue its current course. Despite the challenges of administering ex post substantive standards, the Constitution seems to demand this type of case-by-case review. The high "grossly disproportional" standard could create a workable judicial doctrine that prevents excessive liability but constrains courts from interfering with most fines. If it does not, limiting per offense charges may be the next best solution.

\section{Conclusion}

The Supreme Court's latest attempt to control excessive fines is its best effort yet. Bajakajian gives meaning to the Eighth Amendment's Excessive Fines Clause and provides protection to defendants when the legislature abuses its discretion. Despite administrative difficulties determining when a fine becomes excessive, ex post proportionality review offers the best hope for constraining congressional fines in a constitutionally acceptable manner. Procedural protections simply cannot solve this substantive problem as well. Courts may vary in their application of the Bajakajian test, but the fact that judges may only reduce, not eliminate, excessive fines limits the damages from inconsistent application. Similarly, the fact that only grossly disproportionate fines will be altered constrains the cases that courts will consider and provides at least some deference for legislative judgment. In the end, health care providers benefit from the FCA's per offense charge becoming presumptive rather than mandatory, even if courts apply the standard imperfectly.

Activating the Excessive Fines Clause will not resolve all provider complaints with the FCA or the government's enforcement initiatives. It may, however, offer providers a shield against unjust applications of the FCA. Perhaps, this constitutional protection will embolden more providers to fight their cases in court when they believe that they are the victims of overzealous, inappropriate prosecutions. If nothing more, the Excessive Fines Clause can be used as a bargaining chip in settlement discussions for the nearly 3,500 civil cases currently pending. ${ }^{141}$ Whatever the ultimate impact, in a system of checks and balances, it is important for the court to monitor and curb potential injustices created by the legislative and executive branches. Ex post substantive review of fines can accomplish this.

\section{Acknowledgments}

I thank Daryl Levinson and Walter Wadlington for their invaluable assistance with my article and Nancy Ballengee for inspiring me to learn more about medicine. 


\section{References}

1. The Health Care Finance Administration (HCFA) defines fraud as the "intentional deception or misrepresentation that an individual knows to be false or does not believe to be true and makes, knowing that the deception could result in some unauthorized benefit." Health Care Finance Administration, Medicare Definition of Fraud (visited Oct. 6, 1999) <http://www.hcfa.gov/ medicare/fraud/DEFINI2.HTM>.

The actual cases the government has pursued, however, have frequently extended beyond this definition. See L. Aussprung, "Fraud and Abuse," Journal of Legal Medicine, 19 (1998): 1-63, at 1-2, 6-7 (detailing a history of the government's fraud enforcement initiatives, including the government's aggressive pursuit of cases that push the line between negligence and reckless disregard); see also E. Friedman, "A Concerned Optimist: An 'Exit Interview' with Bruce Vladeck, PhD," JAMA, 281 (1999): 75761 (Bruce Vladeck, former administrator of HCFA, admits that investigation and prosecution of teaching hospitals and hospital billing issues have been too broad).

2. See, for example, Office of Inspector General, Department of Health and Human Services, Semiannual Report, October 1, 1998-March 31, 1999 (1999), available at <http:// www.hhs.gov/oig/semann/99semi1.pdf > (indicating that improper payments under Medicare fee-for-service alone were estimated at $\$ 12.6$ billion during fiscal year 1998 , down 45 percent from fiscal year 1996) [hereinafter Semiannual Report].

3. See J. West, "The False Claims Act: Potential Liability for Health Care Providers for Fraud and Abuse and Beyond," Journal of Health and Hospital Law, 26 (1995): 15 (citing General Accounting Office, Health Insurance: Vulnerable Payers Lose Billions to Fraud and Abuse (Washington, D.C.: U.S. General Accounting Office, GAO/HRD-92-69, May 1992): at 1).

4. See United States $v$. Krizek, 7 F. Supp. 56, 60 (D.C. Cir. 1998); and Obio Hospital Association v. Shalala, 978 F. Supp. 735, 738 (N.D. Ohio 1997).

5. See "Hospitals Call for a Halt to Hounding by Federal Fraud Investigators," Health Legislation o Regulation Weekly, July 16, 1997 (citing the president of the American Hospital Association (AHA) commenting in a letter addressed to U.S. Attorney General Janet Reno, Department of Health and Human Services Secretary Donna Shalala, and Inspector General June Gibbs Brown); and "Doctors Also Feel the Anti-Fraud Pinch," Health Legislation of Regulation Weekly, Aug. 20, 1997 (noting that at the annual meeting of the American Medical Association (AMA), the House of Delegates resolved to fight the government's current trend of prosecuting inadvertent billing errors).

6. See "Provider Groups Challenge Hospital Audits," Health Legislation of Regulation Weekly, Nov. 5, 1997 (noting that the Association of American Medical Colleges, AMA, AHA, and other groups filed suit in California to enjoin the government's Physicians at Teaching Hospitals (PATH) audits); see also Obio Hospital Association, 978 F. Supp. 735 (noting that the Ohio Hospital Association and AHA filed suit for declarative and injunctive relief to prevent the government's national hospital outpatient laboratory enforcement initiative. The case was dismissed for lack of subject matter jurisdiction).

7. Although Congress raised fines aimed at curbing health care fraud and abuse under the Civil Monetary Penalty Act in 1996 (when it passed the Health Insurance Portability and Accountability Act), today the pendulum appears to be swinging in the other direction. See E.M. Apisson, "Double Jeopardy and the Civil Monetary Penalties Dilemma: Is Hudson the Cure for Health Care Fraud and Abuse?," Administrative Law Review, 51 (1999): 283-99, at 288. The Health Care Claims Guidance Act, proposed in 1998 and described below, indicates that Congress is currently more concerned with curbing prosecutorial excesses than fighting fraud.

8. See Health Care Claims Guidance Act, H.R. 3523, 105th Cong. (1998); see also "AHA Backs Cochran-Hollings Bill to Amend False Claims Act," Healthcare Financial Management, 52, no. 6 (1998), available at 1998 WL 13836601 (sponsored by Sen. Thad Cochran (R. Miss.) and Sen. Ernest Hollings (D. S.C.)).

9. See H.R. 3523, 105th Cong. (1998); and "AMA Backs Cochran-Hollings Bill," id.

10. See H.R. 3523, 105th Cong. (1998).

11. See "AMA Backs Cochran-Hollings Bill," supra note 8.

12. See United States $v$. Halper, 490 U.S. 435,449 (1989).

13. See United States v. Krizek, 7 F. Supp. 2d 56, 60 (D.C. Cir. 1998).

14. See Obio Hospital Association v. Shalala, 978 F. Supp. 735, 742 (N.D. Ohio 1997).

15. See Aussprung, supra note 1 , at 3.

16. In addition to the cases cited above, see United States $v$. Diamond, 657 F. Supp. 1204, 1206 (S.D.N.Y. 1987) (decrying the lack of relationship between the fine imposed and the illicit gain); see also United States $\nu$. Orleans Parish School Board, 46 F. Supp. 2d 546, 565 (E.D. La. 1999) (a nonhealth care case finding the fines imposed by the False Claims Act (FCA) excessive and reducing the per claim fine from almost $\$ 8$ million to $\$ 100,000)$.

17. See "New DOJ/OIG Guidelines Set Limits for Fraud Investigations," Healthcare Financial Management, 52, no. 8 (1998), available at 1998 WL 13836652 (quoting letters by Department of Justice (DOJ) Deputy Attorney Eric Holder and Inspector General June Gibbs Brown).

18. For a copy of DOJ's new guidelines, see < http:// www.aha.org/grassroots/guidance.html $>$.

19. See Semiannual Report, supra note 2.

20. "The Provider Self-Disclosure Protocol," 63 Fed. Reg. 58,399 (Oct. 30, 1998). For sector-specific model compliance plans, see, for example, 63 Fed. Reg. 8,987 (Feb. 23, 1998) (hospital compliance plan); 63 Fed. Reg. 45,076 (Aug. 24, 1998) (clinical laboratory compliance plan); 63 Fed. Reg. 42,410 (Aug. 7, 1998) (home health compliance plan); and 63 Fed. Reg. 70,138 (Dec. 18, 1998) (third-party medical billing compliance plan).

21. See "Top DOJ Official Says No Easing of Crackdown on Health Care Fraud," 3 Health Care Fraud Report (BNA), 385 (1999).

22. See General Accounting Office, Medicare Fraud and Abuse: DOJ's Implementation of False Claims Act Guidance in National Initiatives Varies (Washington, D.C.: U.S. General Accounting Office, GAO/HEHS-99-170, Aug. 6, 1999) (citing cases involving a large number of claims being aggressively pursued based on inadvertent error, as well as other continuing problems with the DOJ's enforcement techniques).

23. See $i d$. (reporting that fifteen state hospital associations continue to report concerns with the government's use of the FCA after issuance of the new guidelines).

24. The new guidelines, along with the General Accounting Office, report monitoring compliance is the result of a compromise between the Office of Inspector General (OIG), DOJ, and Congress. See "New DOJ/OIG Guidelines," supra note 17. Congress agreed not to proceed with its Health Care Claims Guidance Act if OIG and DOJ were able to reform effectively their own enforcement techniques. In light of the continuing concerns, it remains to be seen whether Congress will eventually consider some legislation necessary.

25. See A. Few, "Fighting the Battle Against Health Care Fraud: Federal Enforcement Actions," Florida Bar Journal, 72 (Apr. 1998): 34-40, at 34-35.

26. See United States v. Halper, 490 U.S. 435 (1989) (finding 
health care provider's potential liability of $\$ 130,000$ under the FCA grossly disproportionate to the government's losses of $\$ 16,000)$.

27. See, for example, Kennedy v. Mendoza-Martinez, 372 U.S. 144 (1963).

28. Courts and constitutional scholars have expressed concern that Congress, in response to drug trafficking and government contracting fraud, has begun circumventing traditional criminal protections by punishing conduct with civil sanctions. Congress may prefer civil sanctions because they cost less money, take less time to prosecute, and achieve a higher conviction rate because the government only needs to prove its case by a preponderance of the evidence. Courts have been somewhat uncomfortable allowing Congress to exercise this power unchecked, but they have encountered difficulty distinguishing cases in which civil sanctions do and do not warrant criminal procedural protections. See L. Levy, A License to Steal: The Forfeiture of Property (Chapel Hill: University of North Carolina Press, 1996); see also Hudson v. United States, 118 S. Ct. 488, 501 (1997) (Stevens, J., concurring) (voicing concern over Congress's aggressive use of civil fines for punishment).

29. See Hudson, $118 \mathrm{~S}$. Ct. at 491-94.

30. See United States v. Bajakajian, 524 U.S. 321 (1998) (using the Excessive Fines Clause to strike down the application of a forfeiture statute as grossly disproportionate to the defendant's offense and the government's harm).

31. Although the arguments presented in this article address the health care industry, the analysis of the FCA applies to other industries that routinely submit a large number of claims to the federal government.

32. For the Civil Monetary Penalties Law, see 42 U.S.C. $\$$ $1320 \mathrm{a}-7 \mathrm{a}$ (1998) (establishing civil fines of $\$ 10,000$ per violation and treble damages, as well as exclusion from state programs for violations described in 42 U.S.C. $\$ 1320 \mathrm{a}-7 \mathrm{~b})$. For the Program Fraud Civil Remedies Act, see 31 U.S.C. $\$$ S 3801-3812 (1998) (imposing $\$ 5,000$ for false claims in addition to double damages). Both statutes only apply if DOJ decides not to proceed under the FCA. These statutes are particularly troubling because they may only require a showing of negligence.

33. See "Compliance with Laws and Regulations for Health Care Organizations," Healthcare Financial Management, 52, no. 9 (1998), available at 1998 WL 13836719 (describing high-profile settlements for hundreds of millions of dollars).

34. See False Claims Act, 31 U.S.C. \$ 3729(a) (1998).

35. See T. Fitzgerald, "Health Care Providers Encounter the Civil False Claims Act," Colorado Lawyer, Jan. 1999, 65-72, at 65; see also C. Pereyra-Suarez, "Litigation Issues in Fraud and Abuse," Whittier Law Review, 19 (Fall 1997): 51-67, at 65 (discussing how one billing or coding error can infect thousands of claims).

36. See Few, supra note 25.

37. DOJ can issue a civil investigative demand that requires the production of documents, answers to interrogatories, and oral testimony. See 31 U.S.C. $\$ 3733$ (1998).

38. In most published cases, conduct is more flagrant, but in Cedars-Sinai Medical Center v. Shalala, 939 F. Supp. 1457 (C.D. Cal. 1996), an FCA suit was brought against 131 hospitals for noncompliance with a manual provision stating that investigational medical devices were not covered. There is concern that inadvertent noncompliance with published regulations is increasingly being used to bring FCA suits. See R. Hayman, Dissecting a Health Care Fraud Investigation (New York: Practicing Law Institute, Corporate Law and Practice Course Handbook Series, June 1999): 223-44, at 232.

39. 31 U.S.C. $\$ 3729$ (b) (1998).
40. For instance, SmithKline Beecham (SKB) settled a case with the federal government for $\$ 325$ million. One allegation against SKB was "code jamming." Code jamming occurs when lab personnel pick a diagnostic code for use on the claim form because they do not have a specific code for the procedure. This convenience, while perhaps objectionable, was viewed by the government as fraud. See R. Clarke, "Compliance Concerns," Healthcare Financial Management, 52, no. 8 (1998), available at 1998 WL 13836658.

41. See P. Kalb, "Health Care Fraud and Abuse," JAMA, 282 (1999): 1163-68; Pereyra-Suarez, supra note 35, at 63 (noting that a provider is responsible for mistakes made by a billing company if the provider gave the billing company its government provider number); see also J. Russo, "Is Contingency-Free Consulting an Endangered Species?," Healthcare Financial Management, 53, no. 10 (1999), available at 1997 WL 19307362; United States v. Metzinger, C.A. No. 94-7520, 1995 U.S. Dist. LEXIS 6074, (E.D. Pa. 1995) (several hospitals were sued for using a revenuemaximizing consulting company whose billing practices included upcoding, unbundled, and rebundled laboratory procedures).

42. See "Compliance with Laws and Regulations for Health Care Organizations," supra note 33 (describing the complex, everchanging nature of health care regulations).

43. See "Hospitals Call for a Halt to Hounding by Federal Fraud Investigators," supra note 5 .

44. See General Accounting Office, Medicare: Concerns With Physicians at Teaching Hospitals (PATH) Audits (Washington, D.C.: U.S. General Accounting Office, GAO/HEHS-98-174, July 1998) (discussing audit of Dartmouth-Hitchcock Medical Center based on the number of residents criticized); and General Accounting Office, supra note 22 (describing over 100 hospitals targeted improperly based on size or without evidence of false claims).

45. See Aussprung, supra note 1.

46. See "Compliance with Laws and Regulations for Health Care Organizations," supra note 33 (describing the financial incentive created by the FCA).

47. See General Accounting Office, supra note 22 (describing problems with some local enforcement strategies). FCA).

48. See 31 U.S.C. $\$ 3730$ (1998) (qui tam provision of the

49. See T. Anderson, "Home Health, Long-Term Care, and Other Compliance Activities," Healthcare Financial Management, 53 , no. 4 (1999), available at 1999 WL 9968033.

50. See A. Snyder, "The False Claims Act Applied to Health Care Institutions: Gearing Up for Corporate Compliance," DePaul Journal of Health Care Law, 1 (Fall 1996): 1-54, at 16.

51. See 31 U.S.C. $\$ 3729$.

52. See United States v. Halper, 490 U.S. 435, 446 (1989) (stating that the government is entitled to rough remedial justice, but that, at some point, a fine becomes grossly disproportionate to the offense).

53. In an even more extreme case, the government could have no actual damages from the 500 claims. After all, the FCA does not require that the government prove any actual damage. See Rex Trailer Co. v. United States, 350 U.S. 148 (1956). The provider would still be liable for $\$ 2.5$ million in per claim charges.

54 . Of course, the government may also justify the additional penalty because of increased culpability. That argument is addressed below.

55. Throughout the article, I use the term prolific offender to refer to a health care provider that faces enormous potential liability under the FCA due to the large number of claims it has submitted to the government.

56. The per offense charge was never intended to denote greater culpability; rather, Congress included it to ensure that the 
government would be fully compensated for its losses. The current application of the per offense charge to prolific offenders grossly exceeds its mandate. See United States ex rel. Marcus $\nu$. Hess, 317 U.S. 537, reh'g denied, 318 U.S. 799 (1943) (articulating the justification for the per offense charge). See also 132 Cong. Rec. S15054 (1986) (expressing concern that one per offense fine may impose too great a burden on some businesses).

57. If the highest per offense charge is applied, the prolific offender could face liability of $\$ 5.3$ million. Reaching this conclusion, some courts have circumvented the unjust result by manipulating the number of false claims in an intellectually dishonest way. See, for example, United States $v$. Krizek, 7 F. Supp. 56 (D.C. Cir. 1998) (holding that claims only violate the FCA when they result in bills for service hours that exceed twenty-four hours a day, not including any hours that were billed to private insurance during that day). Although this approach may produce justice in the individual case, it does not result in a reliable precedent for other providers. After all, not all courts will disregard the plain meaning of a statute to achieve more just results. Moreover, intellectual dishonesty, while arguably necessary in some FCA cases, undermines the integrity of the judicial system.

58. See Pereyra-Suarez, supra note 35 , at 65 (describing how one billing mistake can infect all claims submitted by a provider and lead to liability that would bankrupt the provider).

59. See, for example, United States v. Killough, 848 F.2d 1523 (11th Cir. 1988); and United States v. Hughes, 585 F.2d 284, 286 (7th Cir. 1978).

60. See Kennedy v. Mendoza-Martinez, 372 U.S. 144 (1963).

61. See id. at 165-66.

62. Id. at 168 .

63. Id.

64. United States $v$. Ward, 448 U.S. 242 (1980).

65. See id. at 242.

66. See id. at 250 .

67. Id. at 251 .

68. United States $v$. Halper, 490 U.S. 435, 438-39 (1989) (stating that fines under the FCA are civil not criminal remedies).

69. Contrast the Civil False Claims Act, 31 U.S.C. SS 3729 3730 (1998), with the Criminal False Claims Act, 18 U.S.C. \$\$ 286-287 (1998).

70. See Ward, 448 U.S. at 250.

71. See id. at 251.

72. See United States $\nu$. Halper, 490 U.S. 435, 442 (1989).

73. See id.

74. See id. at 437.

75. See id. at 449.

76. See id. at 437. If the government's costs for investigation and prosecution are included, total government losses rise to $\$ 16,000$ - the amount that the defendant was ultimately forced to pay.

77. See id. at 449-52.

78. See Hudson v. United States, 118 S. Ct. 488, 494 (1997) (describing Halper's precedent as "unworkable").

79. See Department of Revenue of Montana $v$. Kurth Ranch, 511 U.S. 767 (1994); and United States $\nu$. Ursery, 518 U.S. 267 (1996).

80. See Hudson, $118 \mathrm{~S}$. Ct. at 495 (describing the confusion created by Halper).

81. See United States v. Hughes, 585 F.2d 284 (7th Cir. 1978); United States $v$. Killough, 848 F.2d 1523 (11th Cir. 1988); United States $\nu$. McLeod, 721 F.2d 282 (9th Cir. 1983); but see Peterson v. Weinberger, 508 F.2d 45, 55 (5th Cir. 1975) (judges have discretion to reduce fines). See also S. Rep. 99-345, 99 th Cong., $2 \mathrm{~d}$ Sess. (1987) ("[The FCA has been amended] to raise the fixed statutory penalty from $\$ 2000$ to $\$ 10,000$... the Committee reaf- firms the apparent belief of the Act's initial drafters that defrauding the government is serious enough to warrant an automatic forfeiture rather than leaving final determinations with district courts, possibly resulting in discretionary nominal payments.").

82. See. U.S. Const. amend. VIII ("Excessive bail shall not be required, no excessive fines imposed, nor cruel and unusual punishment inflicted."). The Supreme Court has interpreted the Cruel and Unusual Punishment Clause to prohibit only punishment that is grossly disproportionate to the criminal offense. See Solem $v$. Helm, 463 U.S. 277, 288 (1983).

83. The Supreme Court appears poised to strike down use of the electric chair in Florida as cruel and unusual punishment because several inmates have caught fire before dying; but this extraordinary level of cruelty is required before the Court will evaluate the proportionality of a criminal sentence. Interestingly, it chose the same grossly disproportionate standard for the Excessive Fines Clause. See United States $v$. Bajakajian, 118 S. Ct. 2028, 2037 (1998). This certainly indicates a desire to constrain review, but the one application, in Bajakajian, appears to interpret gross disproportionality more laxly than the Court has when approaching cruel and unusual punishment.

84. See generally, J.C. Jeffries Jr. and P.B. Stephan III, "Defenses, Presumptions, and Burden of Proof in the Criminal Law," Yale Law Journal, 88 (1979): 1325-1407, at 1370-80 (discussing proportionality and criminal penalties).

85. In particular, federal sentences narrowly tailor punishment to culpability and costs. Under the Sentencing Guidelines, defense attorneys can seek downward departures for cooperation, acceptance of responsibility, coercion, and so forth. Similarly, prosecutors can seek enhancements for criminals in a position of trust, in leadership roles, who injure numerous victims, or who cause a great amount of damages. This more narrowly tailored system avoids the unjust and arbitrary results that can follow from an across the board per offense fine. Although state sentencing guidelines are often not as nuanced as the federal guidelines, they are still significantly more narrowly tailored than the FCA.

86. See Department of Revenue of Montana $v$. Kurth Ranch, 511 U.S. 767, 777 n.14 (1994); and United States $v$. Ursery, 518 U.S. 267 n.2 (1996). Halper also failed, because it determined if criminal procedural protections were required ex post, when the government must be able to determine if criminal procedural pro(tections are merited ex ante. Otherwise, the government could not provide the required protections. It makes little sense to establish a doctrine in which a defendant would have to wait until he was punished to determine whether the punishment was barred by double jeopardy, or would have to provide reports and information that incriminated him before the court could determine whether the right against self-incrimination should apply.

87. See Hudson $\nu$. United States, 118 S. Ct. 488, 494-95 (1997).

88. See Ursery, 518 U.S. at 267 n.2.

89. See Hudson, $118 \mathrm{~S}$. Ct. at 491-94.

90. See id.

91. See id. at 496.

92. See id.

93. See id. at 495.

94. See id.

95. It is theoretically possible for a statute to satisfy the Kennedy-Ward test, triggering criminal procedural protections; but, as mentioned earlier, in light of the extreme deference to Congress, it is practically impossible.

96. United States v. Bajakajian, 118 S. Ct. 2028 (1998).

97. See id. at 2041.

98. See id. at 2037.

99. See id. at 2033. 
100. See id. See also Austin v. United States, 509 U.S. 602 , 609-10 (1993).

101. See Bajakajian, 118 S. Ct. at 2034.

102. See id. at 2036.

103. See id. at 2037.

104. See id. at 2038.

105. See id.

106. See id. at 2039.

107. See id.

108. See id.

109. One concern with this conclusion is that the Eighth Amendment has traditionally only been applied to criminal cases. Several Supreme Court cases indicate, however, that the Excessive Fines Clause applies to civil cases that involve a monetary fine if that fine is "punishment for an offense" rather than merely a remedial measure. See Austin v. United States, 509 U.S. 602, 610 (1993) (holding that even a remedial civil fine is subject to the Excessive Fines Clause if it serves "in part to punish"); and Bajakajian, $118 \mathrm{~S}$. Ct. at 2033-34 (citing Austin with approval); Hudson v. United States, 118 S. Ct. 488, 495 (1997) (the Eighth Amendment protects against excessive civil fines); id. at 502 (Breyer, J., concurring) (the Court could have reached the same decision in Halper by applying the Excessive Fines Clause); Browning-Ferris Industries of Vermont, Inc. v. Kelco Disposal, Inc., 492 U.S. 257, 269-72 (1989) (describing the historical roots of the Excessive Fines Clause as including civil fines); but see $i d$. at 262 ("Our cases long have understood [the Eighth Amendment] to apply primarily, and perhaps exclusively, to criminal prosecutions and punishments").

110. See United States v. Halper, 490 U.S. 435, 449 (1989).

111. See id.

112. See Hudson, 118 S. Ct. at 491.

113. See United States v. Lippert, 148 F.3d 974, 977 (8th Cir. 1998) (inferring from the citation to Austin in Bajakajian that Halper's reasoning, while rejected under double jeopardy analysis, remains appropriate for excessive fines analysis).

114. Compare Hudson, 118 S. Ct. at 495; United States v. Bajakajian, 118 S. Ct. 2028, 2037 (1998); and Halper, 490 U.S. at 449.

115. See Hudson, 118 S. Ct. at 494.

116. See id. at 495 (describing how the Fifth, Fourteenth, or Eighth Amendments might be more appropriate to cure the constitutional ills presented in Halper).

117. See $i d$. at 491-94. Although this explanation appears likely, there are several cautionary notes. First, the Supreme Court's classification of the FCA sanctions as punitive in Halper is dicta, as is the Court's statement that such fines are overwhelmingly disproportional. A lower court will not be bound by this analysis, especially in light of the Court's recent repudiation of the decision. Second, it should be noted that Bajakajian never cites to Halper. This may not be significant, however, because Bajakajian cites Austin, which took its definition of a fine directly from Halper. Besides, Bajakajian arises in a very different context. Third, Bajakajian was a 5-4 decision with an unusual coalition of conservative and liberal judges. It may be difficult to present a situation in which these parties will vote together again, even if the extension is a logical one.

118. See Bajakajian, $118 \mathrm{~S}$. Ct. at 2037.

119. See J. Ely, Democracy and Distrust: A Theory of Judicial Review (Cambridge: Harvard University Press, 1980).

120. BMW of North America, Inc. v. Gore, 517 U.S. 559 (1996). The Supreme Court rejected the argument that punitive damages awards should be reviewed under the Excessive Fines Clause in Browning-Ferris. In that case, it found that the Eighth Amend- ment only limits "fines directly imposed by, and payable to, the government." The Court reasoned that the framers' intent and history both indicate that the Excessive Fines Clause was written to prevent government abuse of prosecutorial power, not to constrain civil damages between private parties. See Browning-Ferris Industries of Vermont, Inc. v. Kelco Disposal, Inc., 492 U.S. 257, 266-68 (1989).

121. See $B M W, 517$ U.S. at $582-85$.

122. See id. at 568 .

123. See id.

124. See C.R. Sunstein, D. Kahneman, and D. Schkade, "Assessing Punitive Damages (With Notes on Cognition and Valuation in Law)," Yale Law Journal, 107 (1998): 2071-2153 (discussing the goals of punitive damages and the procedural problems that create a need for judicial review of damages); see also $T$. Kelley, "Punitive Damages in Media Tort Litigation," PLI/Pat, 523 (July 1998): 359-743 (discussing the history of punitive damages review).

125. See A.M Polinsky and S. Shavell, "Punitive Damages: An Economic Analysis," Harvard Law Review, 111 (1998): 869-962 (discussing the justifications for punitive damages).

126. See id.

127. See Sunstein, Kahneman, and Schkade, supra note 124, at 2074.

128. See id.

129. See id.

130. In practice, attorneys may reach settlements with government officials that make the attorney's skills relevant and decrease the uniform application of fines; but settlements would not be reviewed under the excessive fines analysis. Therefore, factors relevant to fine settlements should not be considered in an evaluation of the ex post proportionality review.

131. See Ely, supra note 119.

132. The U.S. Constitution has no similar provision mandating that punitive damages be reviewed. Constitutional scholars debate whether the Excessive Fines Clause should have been read to include punitive damages in light of the blurring of government and private remedies at the time. See Browning-Ferris Industries of Vermont, Inc. v. Kelco Disposal, Inc., 492 U.S. 257, 286 (1989) (O'Connor, J., concurring in part and dissenting in part) (summarizing numerous articles written on the issue and analyzing the history of the Excessive Fines Clause).

133. "Excessive bail shall not be required, nor excessive fines imposed, nor cruel and unusual punishments inflicted." U.S. Const. amend. VIII.

134. See Austin v. United States, 509 U.S. 602, 622-23 (1993) (the penalty must be compared with the offense).

135. See Alexander v. United States, 509 U.S. 544 (1993) (excessiveness of the forfeiture under the Eighth Amendment must be considered in light of the crime committed).

136. See Browning-Ferris Industries of Vermont, Inc. v. Kelco Disposal, Inc., 492 U.S. 257, 286 (1989); id. at 271 (describing the legal roots of the Excessive Fines Clause in the Magna Carta, which required that the amount of any amercement be proportional to the wrong); and United States v. Bajakajian, $118 \mathrm{~S}$. Ct. 2028, 2036 (1998) (proportionality is the cornerstone of any constitutional inquiry under the Excessive Fines Clause).

137. See Bajakajian, 118 S. Ct. at 2043-44 (Kennedy, J., dissenting).

138. See id. at 2037.

139. The legislature could increase the damages multiplier if necessary to deter malign conduct fully.

140. See United States v. Ursery, 518 U.S. 267, 282-83 (1996).

141. See Kàlb, supra note 41. 